Jpn. J. Genet. (1989) 64, pp. 231-238

\title{
A new gene responsible for an energy-transducing system in Escherichia coli
}

\author{
Masamichi Nakamura*, Masaki Ito, Kiyoshi FuJita \\ and Yasuyuki TAKAGI \\ Division of Molecular Genetics, Institute for Comprehensive Medical Science, \\ Fujita-Gakuen Health University, Toyoake, Aichi 470-11
}

(Received 25 April 1989)

\begin{abstract}
A mutant strain (ttr-3) of Escherichia coli was originally isolated as a strain resistant to tributyltin exhibiting temperature-sensitive depressions of growth and ATP synthesis on succinate plates at $42^{\circ} \mathrm{C}$. The $t$ tr gene was mapped between the $p y r E$ and $d n a A$ genes (in the $82-83 \mathrm{~min}$ region) on the chromosome by P1-transduction experiments. Comparison of proline transport and oxygen uptake by membrance vesicles of the wild-type transductant and the mutant (ttr-3) transductant showed that membrane vesicles of the mutant exhibited temperature-sensitive decrease of proline transport and increase of oxygen uptake at the restrictive temperature $\left(42^{\circ} \mathrm{C}\right)$, compatible with depression of growth of the mutant at this temperature. Therefore, the $t t r$ gene seems to code for some factor involved in the respiratory chain that is present in the inner membrane of Escherichia coli.
\end{abstract}

\section{INTRODUCTION}

ATP synthesis driven by oxidative phosphorylation is observed in the inner membranes of prokaryotes and mitochondria of eukaryotes. The electron transport system, named the respiratory chain, is localized in the inner membranes. Electrons are transported through the respiratory chain from a substrate such as succinate to oxygen, forming an outside-positive, inside-negative proton gradient across the membranes. Based on these observations, Mitchell proposed the chemiosmotic hypothesis (Mitchell, 1966) which states that the electrochemical potential of $\mathrm{H}^{+}\left(\Delta \mu \mathrm{H}^{+}\right)$is a motive force for ATP synthesis. In fact, $\mathrm{H}^{+}$translocating ATPase $\left(\mathrm{H}^{+}\right.$-ATPase) catalyzes ATP synthesis depending upon the proton gradient (Kagawa, 1984).

The chemiosmotic hypothesis can explain many observations on ATP synthesis through the process of oxidative phosphorylation (Mitchell, 1966). However, the mechanism by which protons outside the membrane are transferred to $\mathrm{H}^{+}$. ATPase for ATP synthesis is still unknown. One approach to this problem is to isolate mutant strains defective in some components involved in the energy transducing system. So far unc mutant strains (Gunsalus et al., 1982) and ecf mutant strains (Lieberman and Hong, 1974) of $E$. coli have been isolated by 
genetical approaches. The unc genes are known to code for protein subunits of $\mathrm{H}^{+}$-ATPase (Gunsalus et al., 1982), but the products coded by the ecf genes have not been identified yet.

Previously, we reported isolation of some mutant strains that exhibited temperature-sensitive growth with succinate as a carbon source (Ito and Ohnishi, 1981; Ito et al., 1983). One of them, strain SM434 (ttr-3), is a mutant strain that was originally isolated as a mutant resistant to tributyltin, an inhibitor of energy transducing components, and also resistant to dicyclohexylcarbodiimide (DCCD), another inhibitor of energy transducing components (Michael and Gottschalk, 1985). Furthermore, this mutant exhibits temperature-sensitive ATP synthesis in whole cells with succinate as substrate (Ito et al., 1986). Therefore, this strain is expected to carry a mutation in a factor that is essential for the energytransducing system.

This paper reports mapping of the $t \operatorname{tr}$ gene on the $E$. coli chromosome and studies on proline transport and oxygen uptake by membrane vesicles prepared from the mutant cells. The results obtained support our assumption that the mutation is in a factor involved in the energy-transducing system.

\section{MATERIALS AND METHODS}

\section{I) Bacteria}

The temperature-sensitive mutant strain SM434 (thy, gal, ttr-3) was isolated from the wild-type strain KH434. RE74 (pyrE41, tonA22, relA1, gltSo14, tna-6, $m e t B, T 2^{r}$ ) and JM15 (cysE50, $t f r-8$ ) were furnished by Dr. B. J. Bachmann (Yale University). KH434 and KH1652 (met, uhp-2, rel, dnaA46, pyrE, tonA22, T2 $2^{r}$, $b g l R, t n a)$ were gifts from Dr. T. Horiuchi (Kyushu University). HE1 ( $p y r E^{+}$, a P1-transductant of RE74 from SM434), HE2 (pyrE ${ }^{+}$, ttr-3, a P1-transductant of RE74 from SM434), FG11 (dnaA ${ }^{+}$, a P1-transductant of KH1652 from SM434), FG12 (dnaA ${ }^{+}$, ttr-3, a P1-transductant of KH1652 from SM434) and IM5 (HfrC, $i l v A, r e l, t n a$, tonA22, $b g l, T 2^{r}$ ) were constructed in this laboratory.

\section{II) Media}

M63 medium (Miller, 1972) was used as a minimal medium with $40 \mathrm{mM}$ sodiumsuccinate or $0.4 \%(\mathrm{~W} / \mathrm{V})$ glucose as the carbon source. Thymine was added at a final concentration of $10 \mu \mathrm{g} / \mathrm{ml}$ for growth of strain SM434. L-broth supplemented with $10 \mu \mathrm{g}$ thymine/ml was used as a rich medium.

Table III) Chemicals.

L- $\left[{ }^{14} \mathrm{C}\right]$ proline $(262 \mathrm{mCi} / \mathrm{mmol})$ was purchased from New England Nuclear. Chloramphenicol and lysozyme were obtained from Sigma Chemical Co. 


\section{IV) Methods}

1) Temperature-sensitivity of phenotype

Cells were washed and suspended in M63 medium. Inocula of $10^{6}$ cells on M63 plates containing glucose or succinate were incubated at $30^{\circ} \mathrm{C}$ or $42^{\circ} \mathrm{C}$ for 2 days. A cell that did not form a colony on a plate with succinate at $42^{\circ} \mathrm{C}$ was regarded as the temperature-sensitive mutant.

2) P1-transduction experiments

Recipient strains JM15, RE74, KH1652 and IM5, defective in the cysE, pyrE, $d n a A$ and $i l v A$ genes, respectively, were infected with phage P1vir grown on a mutant strain SM434 (ttr-s). Then, $100 \mathrm{cysE}^{+}, \mathrm{pyrE}{ }^{+}, d n a A^{+}$and $i l v A^{+}$ transductants each were selected. The temperature-sensitivity of transductants was examined as described above.

3) Preparation of membrane vesicles

Membrane vesicles were prepared by lysozyme-EDTA treatment by the method of Kaback (1971) from a wild-type strain HE1 (RE74 pyrE ${ }^{+}$) and a mutant strain HE2 (RE74 pyrE $^{+}$ttr-3).

4) Measurement of proline transport of membrane vesicles

The reaction mixture $(1 \mathrm{ml})$ consisted of $0.1 \mathrm{M}$ potassium phosphate buffer, $\mathrm{pH}$ $7.2,40 \mu \mathrm{g} / \mathrm{ml}$ chloramphenicol, $4 \times 10^{-4} \mathrm{M}\left[{ }^{14} \mathrm{C}\right]$ proline, $5 \mathrm{mM}$ succinate and membranes (100 $\mu$ grotein) (Kaback, 1971). A reaction mixture without succinate was incubated at $30^{\circ} \mathrm{C}$ or $42^{\circ} \mathrm{C}$ for $5 \mathrm{~min}$, and then the reaction was started by addition of succinate. Aliquots $(0.1 \mathrm{ml})$ of the reaction mixture were taken at 30 sec intervals and promptly applied to a membrane filter disc (Sartorius; pore size $0.45 \mu \mathrm{m}$ ) under suction. The filter was washed with $10 \mathrm{ml}$ of $10 \mathrm{mM}$ Tris-HC1, $\mathrm{pH} 7.2$, containing $0.15 \mathrm{M} \mathrm{NaCl}$ and $0.5 \mathrm{mM} \mathrm{MgCl}_{2}$, dried and counted in a liquid scintillation spectrometer. A reaction mixture with $30 \mathrm{mM}$ sodium azide was used as a control.

5) Measurement of oxygen uptake of membrane vesicles

Membrane vesicles were suspended in M63 medium at a concentration of 200 $\mu \mathrm{g} / \mathrm{ml}$ protein. Oxygen uptake was measured at $30^{\circ} \mathrm{C}$ or $42^{\circ} \mathrm{C}$ with a Clark-type oxygen electrode with succinate as substrate.

6) Protein determination

Protein was determined with a protein assay kit from Bio-Rad with bovine serum albumin as a standard.

\section{RESULTS AND DISCUSSION}

I) Mapping of the ttr gene

The ttr-3 mutant, exhibiting temperature-sensitive growth with succinate as a carbon source, was shown to be complemented by F111, which carries a partial chromosome (81 min-91 min) of $E$. coli (Low, 1973; Ito et al., 1986). Therefore, the linkages between the $t r$ gene and the $i l v A(84.6 \mathrm{~min}), d n a A(83.1 \mathrm{~min}), p y r E$ $(81.8 \mathrm{~min})$ and $c y s E(81 \mathrm{~min})$ genes were examined by P1-transduction experiments to determine the location of the $t t r$ gene on the $E$. coli chromosome. 
Strain RE74 (pyrE) was infected with phage P1vir grown on the mutant strain SM434 (ttr-3) and pyrE $E^{+}$transductants were selected. Eight of 100 transductants did not grow on succinate at $42^{\circ} \mathrm{C}$. Similarly, strain KH1652 (dnaA) was infected with phage P1vir grown on the mutant strain SM434 and dnaA ${ }^{+}$ transductants were selected. Five of 100 transductants did not grow on succinate at $42^{\circ} \mathrm{C}$. These results indicate that the $t t r$ gene is linked to the pyrE gene at a frequency of $8 \%$, and to the $d n a A$ gene at a frequency of $5 \%$. However, no linkage of the $t \operatorname{tr}$ gene to the $i l v A$ gene or $c y s E$ gene was observed in experiments using strain IM5 ( $i l v A)$ or strain JM15 (cysE) as the recipient strain. From these P1-transduction experiments the $t$ tr gene was concluded to be located in the 82-83 min region on the $E$. coli chromosome (Fig. 1). The temperature-sensitivity of transductants from strain RE74 and strain KH1652 is shown in Fig. 2.

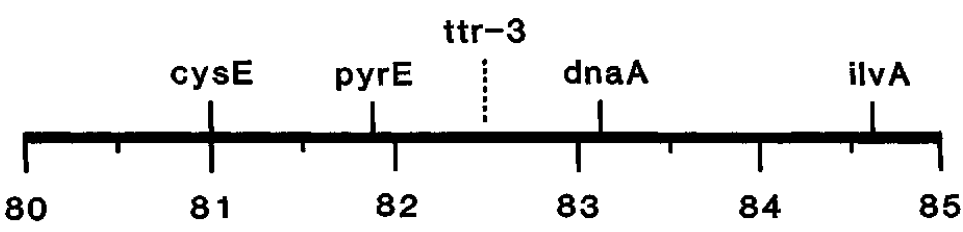

Fig. 1. Location of the ttr-3 mutation on the $E$. coli chromosome. The gene locations (in minutes) are based on the 100-min $E$. coli linkage map (Bachmann, 1983). The position of $t$ tr-3 was determined in the $82-83 \mathrm{~min}$ by Pl-transduction experiments.

\section{II) Temperature-sensitivity of proline trasport by membrane vesicles}

We reported previously that intact cells of the $t$ tr- $s$ mutant strain exhibited temperature-sensitivity at the level of ATP synthesis (Ito et al ., 1986). Membrane vesicles are known to show proline transport coupled with an energygenerating system dependent upon the respiratory chain (Kobayashi et al., 1974). Thus membrane vesicles prepared from the mutant strain were assayed for proline transport activity. The time courses of proline transport driven by succinate in membrane vesicles from the wild-type transductant HE1 (RE74 pyrE ${ }^{+}$) and the mutant transductant HE2 (RE74 $p y r E^{+} t$ tr-s) were measured at $30^{\circ} \mathrm{C}$ and $42^{\circ} \mathrm{C}$. The membranes from both strains exhibited equilibration of proline transport $3 \mathrm{~min}$ after the addition of succinate. The proline transport activity of membranes from the wild-type strain $\mathrm{HE1}$ was similar at $30^{\circ} \mathrm{C}$ and $42^{\circ} \mathrm{C}$, but that of membranes from the mutant strain HE2 was clearly lower at $42^{\circ} \mathrm{C}$ than at $30^{\circ} \mathrm{C}$. Thus, membrane vesicles from the mutant strain HE2 exhibited temperature-sensitivity of proline transport driven by succinate (Fig. 3). 


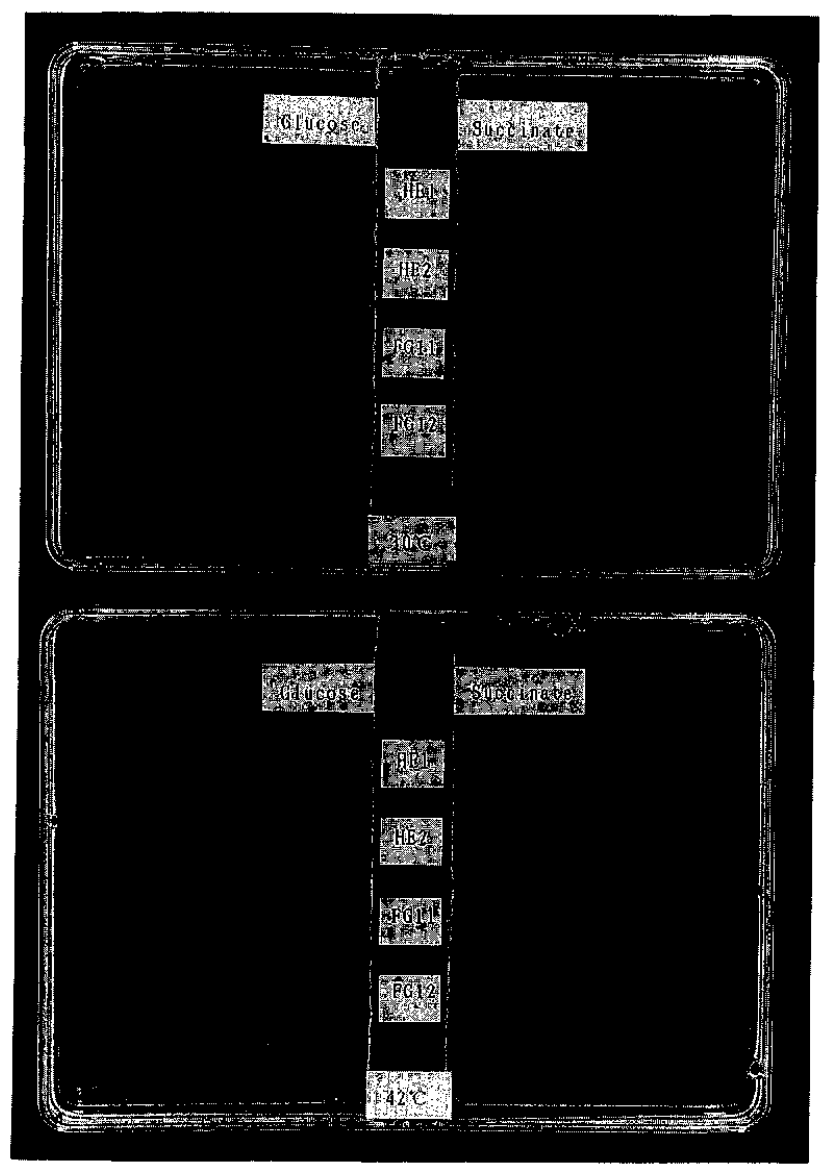

Fig. 2. Temperature-sensitivity of transductants. Strains HE1 (RE74 $\left.p y r E^{+}\right)$, HE2 (RE74 pyrE $\left.{ }^{+} t t r-3\right)$, FG11 (KH1652 $\left.d n a A^{+}\right)$and FG12 (KH1652 dnaA $\left.A^{+} t r-3\right)$ were incubated on plates containing $0.4 \%(\mathrm{~W} / \mathrm{V})$ glucose or $40 \mathrm{mM}$ succinate at $30^{\circ} \mathrm{C}$ or $42^{\circ} \mathrm{C}$ for 2 days.

\section{III) Oxygen uptake by the membrane vesicles}

The $t t r$ gene may code for a component of the respiratory chain. If so, membrane vesicles prepared from the $t$ tr-3 mutant strain should show altered oxygen uptake (Kobayashi et al., 1974). Therefore, we measured oxygen uptake by membrane vesicles from the wild-type strain HE1 and from the mutant strain HE2 at $30^{\circ} \mathrm{C}$ and $42^{\circ} \mathrm{C}$ with a Clark-type oxygen electrode. Membrane vesicles prepared from the wild-type strain HE1 showed the similar rate of oxygen uptake at $30^{\circ} \mathrm{C}$ and $42^{\circ} \mathrm{C}(113 \mu \mathrm{mol} / /$ and $141 \mu \mathrm{mol} / /$, respectively $)$, whereas those from the ttr-s mutant strain $\mathrm{HE} 2$ showed higher oxygen uptake at $42^{\circ} \mathrm{C}$ than at $30^{\circ} \mathrm{C}$ $(385 \mu \mathrm{mol} / /$ and $226 \mu \mathrm{mol} /$, respectively) (Fig. 4). 

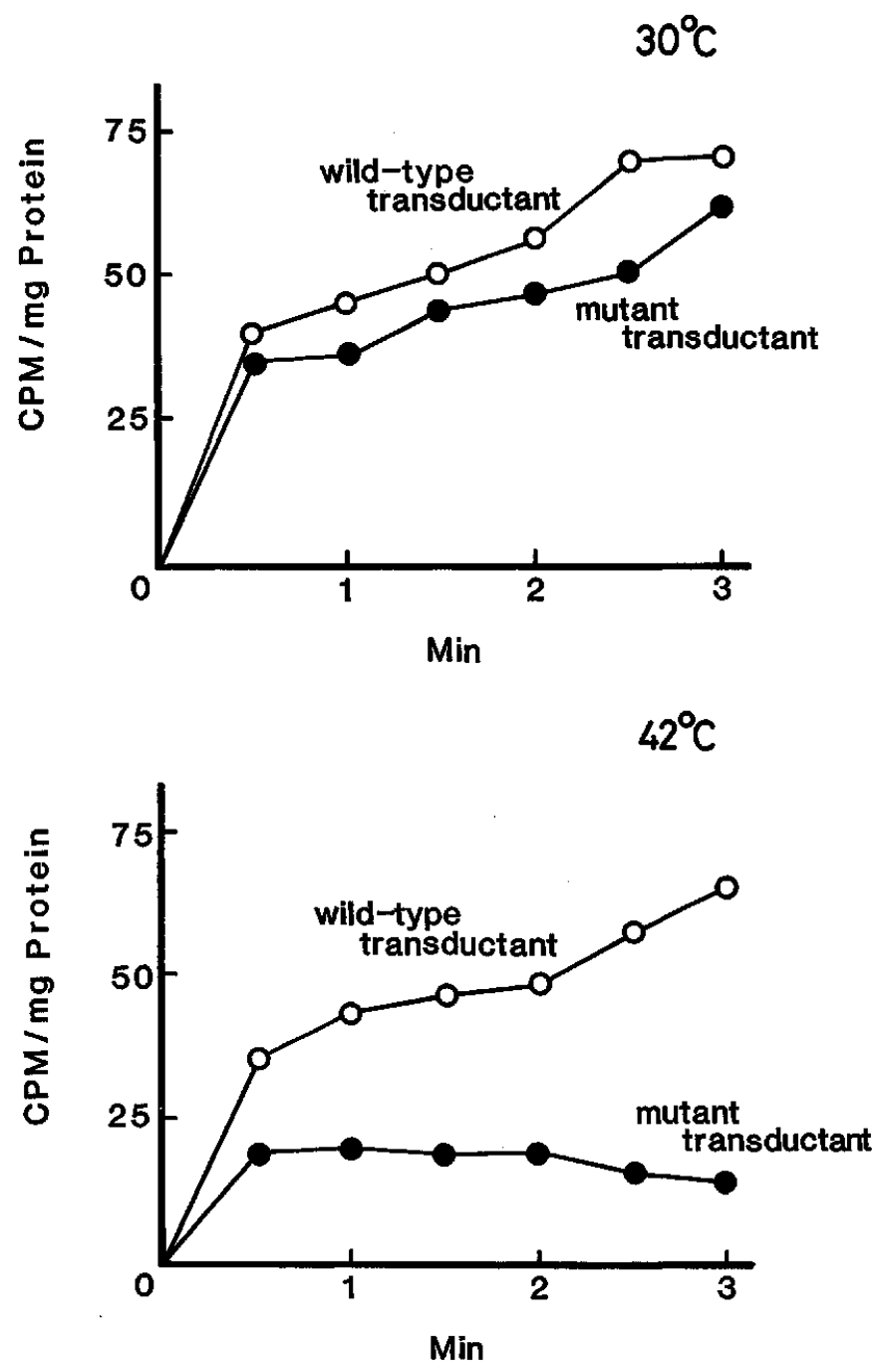

Fig. 3. Defective proline-transport in membrane vesicles prepared from the $t t r-3$ mutant strain. Membrane vesicles from the wild-type transductant HE1 and the mutant transductant HE2 were prepared according to Kaback (1971). The reac-

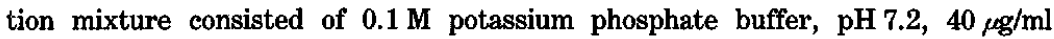

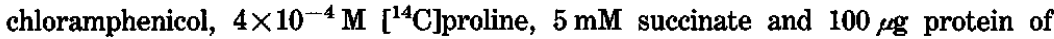
membrane. No proline-transport was observed in a control reaction mixture with $30 \mathrm{mM}$ sodium azide.

In the present study we found that with succinate as substrate, membrane vesicles from the mutant strain HE2 (ttr-s) exhibited decreased proline-transport and increased oxygen uptake at $42^{\circ} \mathrm{C}$. These findings support the concepts that the $t$ tr gene codes for a component of the respiratory chain supplying energy 

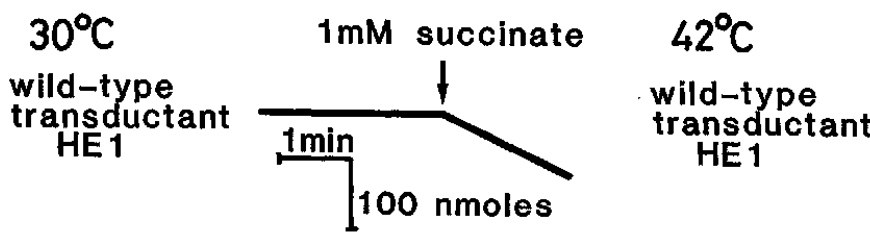

$1 \mathrm{mM}$ succinate
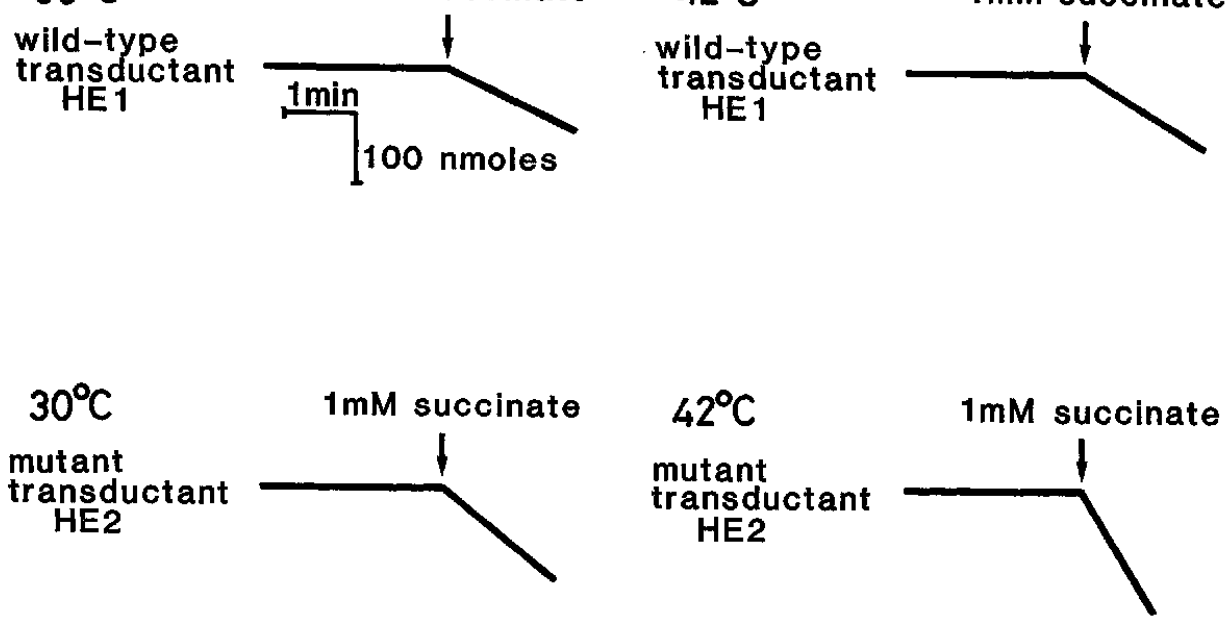

Fig. 4. Stimulation of oxygen uptake at the restrictive temperature $\left(42^{\circ} \mathrm{C}\right)$ in membrane vesicles prepared from the $t t r-3$ mutant strain. Membrane vesicles were prepared from the wild-type strain and the ttr-s mutant strain according to Kaback (1971), and suspended in M63 medium at a concentration of $200 \mu \mathrm{g} / \mathrm{ml}$ protein. The vesicles were pre-incubated at $30^{\circ} \mathrm{C}$ or $42^{\circ} \mathrm{C}$ for $5 \mathrm{~min}$, and the oxygen uptake was measured with $1 \mathrm{mM}$ succinate as respiratory substrate with a Clark-type oxygen electrode.

necessary for proline-transport and that mutation of this gene might result in uncoupling of respiration and ATP-synthesis.

In addition, to determine whether the $t t r$ gene is distinct from any known gene coding for a protein that is essential in the energy-transducing system, we examined the location of the $t$ tr gene on the $E$. coli chromosome by P1transduction experiments and found that this gene is located in the $82-83 \mathrm{~min}$ region on the $E$. coli chromosome.

The unc genes and ecf genes are also known to be related to the energy transduction system. However, the unc genes located at $84 \mathrm{~min}$ on the $E$. coli chromosome are linked to the $i l v A$ gene and code for protein subunits of $\mathrm{H}^{+}$ATPase (Gunsalus et al., 1982). In contrast, the $t t r$ gene is not linked to the ilvA gene and is located in the $82-83 \mathrm{~min}$ region. Furthermore, we did not observe any alteration of $\mathrm{H}^{+}$-ATPase activity in the $t$ tr- $\&$ mutant strain (data not shown). These results indicate that the $t$ tr gene is different from the unc genes.

The ecfA (65 $\mathrm{min})$ and ecfB $(88 \mathrm{~min})$ genes, which are located in different regions from the $t$ tr gene (82-83 $\mathrm{min}$ ), are also responsible for an energy-coupling system related to proline-transport (Bachmann, 1983; Lieberman and Hong, 1974). However, ecf mutant strains did not exhibit temperature-sensitive oxygen uptake and they were concluded to carry mutations in other component than respiratory chain (Lieberman and Hong, 1974). Thus the $t$ tr gene seems to specify a factor which is different from proteins encoded by the ecf genes. We conclude from this 
study that the $t$ tr gene may code for a protein component of the respiratory chain in the inner membrane of $E$. coli. Further analysis of this temperature-sensitive ttr-3 mutant strain should provide useful information for understanding the molecular mechanism of the energy-transducing system, how protons are transferred through the respiratory chain to $\mathrm{H}^{+}$-ATPase for ATP synthesis.

We thank Drs. B. J. Bachmann (Yale Univ.) and T. Horiuchi (Kyushu Univ.) for providing E. coli strains, and Dr. E. Ichihara for reading manuscript.

\section{REFERENCES}

BaChManN, B. J. (1983) Linkage map of Escherichia coli K-12, Edition 7. Microbiol. Rev. 47, 180230.

Gunsalus, R. P., BRusilow, W. S. A. and Simoni, R. D. (1982) Gene order and gene-polypeptide relationship of the proton-translocating ATPase operon (unc) of Escherichia coli. Proc. Natl. Acad. Sci. USA 79, 320-324.

Іто, M. and OнNiSHI, Y. (1981) Isolation of Escherichia coli mutants which are resistant to inhibition of $\mathrm{H}^{+}$-ATPase, tributyltin and also to uncouplers of oxidative phosphorylation. FEBS Lett. 136, 225-230.

Iто, M., OHNISHI, Y., IтоH, S. and NishimuRA, M. (1983) Carbonyl cyanide-m-chloropheny1 hydrazon-resistant Escherichia coli mutant that exhibits a temperture-sensitive une phenotype. $J$. Bacteriol. 153, 310-315.

Ito, M., Nakamura, M., Nagamune, H., Morikawa, N. and Terada, H. (1986) An Escherichia coli mutant exhibiting temperature-sensitive ATP synthesis. Biochem. Biophys. Res. Commun. 138, $72-77$.

KABACK, H. R. (1971) Enzyme purification and related techniques. [13] Bacterial membranes. Methods in Enzymol. 22, 99-120.

KAGAWA, Y. (1984) A new model of proton motive ATP synthesis: Acid-base cluster hypothesis. $J$. Biochem. 95, 295-298.

KoBaYASHI, H., KIN, E. and ANRAKU, Y. (1974) Transport of sugars and amino acids in bacteria. X. Sources of energy coupling reactions of the active transport systems for isoleucine and proline in E. coli. J. Biochem. 76, 251-261.

LIEBERMAN, M. A. and HoNG, J-S. (1974) A mutant of Escherichia coli defective in the coupling of metabolic energy to active transport. Proc. Natl. Acad. Sci. USA 71, 4395-4399.

Low, K. B. (1973) Escherichia coli F-prime factors, old and new. Bacteriol. Rev. 36, 587-607.

Michael, B. and GotTsChalK, G. (1985) Evidence for a chemiosmotic mecharism of ATP synthesis in methanogenic bacteria. Trends Biochem. Sci. 10, 486-489.

MILLER, J. H. (1972) Experiments in molecular genetics, pp. 82-85, pp. 230-234. Cold Spring Harbor Laboratory, New York.

MITCHELL, P.(1966) Chemiosmotic coupling in oxidative photosynthetic phosphorylation. Biol. Rev. Cambridge Philos. Soc. 41, 445-502. 